\title{
Interdiffusion Studies on Hot Rolled U-10Mo/AA1050
}

\author{
Adonis Marcelo Saliba-Silva*, Ilson Carlos Martins, Elita Fontenelle Urano de Carvalho, \\ Davilson Gomes da Silva, Humberto Gracher Riella, Michelangelo Durazzo
}

\begin{abstract}
Comissão Nacional de Energia Nuclear - CNEN, Centro de Combustível Nuclear - CCN, Instituto de Pesquisas Energéticas e Nucleares - IPEN, Av. Professor Lineu Prestes, 2242, Cidade Universitária, CEP 05508-000, São Paulo, SP, Brazil
\end{abstract}

Received: May 9, 2011; Revised: July 3, 2012

\begin{abstract}
The U-Mo alloys are investigated with the goal to become nuclear material to fabricate high-density fuel elements for high performance research reactors. The enrichment level $\left(20 \%{ }^{235} \mathrm{U}\right)$ suggests that the U-Mo alloys should be between 6 to $10 \mathrm{wt}$. (\%), which can reach up to $9 \mathrm{gU}^{\mathrm{cm}} \mathrm{cm}^{-3}$ in fuel density. Nevertheless, the U-Mo alloys are very reactive with Al. Interdiffusion reaction products are formed since nuclear fission promotes chemical interaction layer during operation, leading to potential structural failure. Present studies were made with treated hot rolled diffusion couples of U-10Mo inserted in $\mathrm{Al}$ (AA1050). The U-10Mo/AA1050 pairs were treated in two temperatures $\left(150{ }^{\circ} \mathrm{C}\right.$ and $\left.550{ }^{\circ} \mathrm{C}\right)$ with three soaking times $(5,40$ and 80 hours). From microstructure analyses, rapid diffusion of $\mathrm{Al}$ happened inside $\mathrm{U}-10 \mathrm{Mo}$ in the first heating at $540{ }^{\circ} \mathrm{C}$ during 15 minutes, reaching 8 at $\% \mathrm{Al}$ in a range of $170 \mu \mathrm{m}$ towards $\mathrm{U}-10 \mathrm{Mo}$. Longer time at $550{ }^{\circ} \mathrm{C}$ treatment maintain this level of Al-content up to $1000 \mu \mathrm{m}$ inside U-10Mo. In this study, the results suggested the formation of a barrier made by residual elements, which promoted little interdiffusion phenomena between U-10Mo and alloy AA1050. Silicon co-diffusion with Al, along the interdiffusion line, is thought to be an important indication for this interdiffusion blockage.
\end{abstract}

Keywords: U-Mo, nuclear fuel, research reactors, interaction layer, Al/U-Mo interdiffusion pair

\section{Introduction}

The need for conversion of HEU (High enriched uranium (enriched $235 \mathrm{U}$ more than $20 \%$ )) research reactors to LEU (Low enriched uranium (enriched 235U less than 20\%)) fronts open goals to seek alternative fuel elements of high uranium density. The developing of a denser core in uranium leads to higher intensity in the neutron flux and smaller amounts of spent fuel to be stored in repositories. The U-Mo alloy has been investigated with the purpose to be nuclear material for making high-density fuel elements for research reactors of high performance. This alloy could have high density in fuel core up to around $9 \mathrm{gU} . \mathrm{cm}^{-3[1-4]}$.

During fuel plates fabrication, the U-Mo alloy would employ the technology for the current LEU fuel geometry ${ }^{5-7}$. U-Mo alloy is very reactive in the presence of aluminum in thermal cycling process. The reaction products are undesirable because they generate a low conductivity interaction layer (IL) by nuclear fission, leading to potential structural failure ${ }^{3,8,9}$. The thermal experiments are normally carried out below $\gamma$-phase temperature formation to simulate the interdiffusion and phases formation in $\mathrm{U}-\mathrm{Mo}-\mathrm{Al}^{10}$. The more common observed phases have been (U,Mo) $\mathrm{Al}_{2}$, (U,Mo) $\mathrm{Al}_{3}$ (U,Mo) $\mathrm{AL}_{4}{ }^{[9]}$.

Ryu et al. ${ }^{9}$ simulated heat-treated growth-layer interaction in $\mathrm{U}-10 \mathrm{Mo} / \mathrm{Al}$ fuel dispersion with treatments of $550{ }^{\circ} \mathrm{C}$ during 40 hours. It was found 3 levels of interaction

*e-mail: saliba@ipen.br layer. The more internal layer had a depth of approximately $500 \mu \mathrm{m}$, displaying the $\mathrm{UAl}_{3}(77.5 \mathrm{at} \% \mathrm{Al})$ as the most structured one $(>400 \mu \mathrm{m})$ towards the center of U-10Mo alloy. Near the contact region, there were 2 other layers ( 50 $\mu \mathrm{m}$ each), having 81.6 at $\% \mathrm{Al}\left(\mathrm{UAl}_{4}\right)$ and 88.3 at $\% \mathrm{Al}$ respectively.

Mirandou et al. ${ }^{11}$ studied thermal treatments at $580{ }^{\circ} \mathrm{C}$ in couples of $\mathrm{U}-7 \mathrm{Mo} / \mathrm{Al}$ and found the formation of $(\mathrm{U}, \mathrm{Mo}) \mathrm{Al}_{3},(\mathrm{U}, \mathrm{Mo}) \mathrm{Al}_{4}$. A very thin layer near the interface was found to be $\mathrm{Al}_{20} \mathrm{UMo}_{2}$. Mirandou et al. ${ }^{11,12}$ studying pairs U-7Mo/Al-6061 and U-7Mo/Al-A356 at $550{ }^{\circ} \mathrm{C}$ and $340{ }^{\circ} \mathrm{C}$, confirmed the presence of Si-phases $\left(\mathrm{U}_{3} \mathrm{Si}_{5}\right)$. The interaction layer depth in this work had just few micrometers accounted to a probable participation with Si diffusion. Al-Si stable alloys were formed and hindered the evolution of aluminum interdiffusion into the U-Mo structure. In the present study, U-10Mo alloy was chosen for presenting a more stable $\gamma$-phase, since $\alpha$-phase formation is very little for the Mo-content ${ }^{3}$. The use of aluminum alloy AA1050 was elected since it was a regular alloy to fabricate MTR (Material Test Reactor. It refers to conceptual technology to build Nuclear Research Reactors, as the IEA-R1 in IPEN/Brazil, which uses a specially projected fuel element named MTR nuclear fuel.) fuel plates and had less latent contaminants than AA6061. In this way, the interdiffusion pair was made by encapsulation and hot rolling $\mathrm{U}-10 \mathrm{Mo} / \mathrm{AA} 1050$, at process temperature 
of $540{ }^{\circ} \mathrm{C}$. In this context, it is feasible to check how far the chemical interaction would happen in practical fuel fabrication.

\section{Experimental}

Natural uranium metal produced by IPEN's magnesiothermic process ${ }^{6,7,13,14}$ was used to produce U-10 wt. (\%) Mo. The uranium ingot, with the composition in Table 1, was pickled with nitric acid (65\%). Stoichiometric amount of Mo was added as cylinders $(3.175 \times 3.175 \mathrm{~mm})$ produced by Alpha Aesar (purity 99.95\%). The mixture $(\mathrm{U}+\mathrm{Mo})$ was loaded in a zirconia crucible and the melting was performed in an induction furnace. Before induction, 3 -cycles of vacuum and argon purging were made. Finally, the melting was made less than $2.0 \times 10^{2}$ mbar (argon atmosphere). A U-10Mo ingot was produced with density of $16.80 \mathrm{~g} . \mathrm{cm}^{-3}$. A homogenization heat treatment $1000{ }^{\circ} \mathrm{C}$ during 72 hours was made in the U-10Mo alloy to ensure better compositional variation in metastable $\gamma$-phase in U-10Mo. This treatment was made inside a sealed retort of SS310 stainless steel with continuous $1 \mathrm{~L} / \mathrm{min}$ flow of argon at 2.45 bar. After annealing, the retort was removed from the oven and kept until reaching room temperature. To prepare the diffusion pairs of U-10Mo/AA1050, the samples U-10Mo were cut in tablet format using diamond wheel cutter, followed

Table 1. Raw Materials to prepare the interdiffusion pairs of U-Mo/AA1050.

\begin{tabular}{|c|c|c|c|}
\hline & Uranium & U-10Mo & AA1050 \\
\hline Elem. & $\mu g \cdot g^{-1}$ & $\mu g \cdot g^{-1}$ & g.g-1 \\
\hline $\mathrm{Al}$ & $110 \pm 3$ & $90.5 \pm 2.7$ & $99.4 \pm 0.1$ \\
\hline B & $<0.4$ & $<0.4$ & - \\
\hline $\mathrm{Ba}$ & $<0.2$ & $1.34 \pm 0.16$ & - \\
\hline $\mathrm{C}$ & $0.11 \%$ & $0.09 \%$ & - \\
\hline $\mathrm{Ca}$ & $6.0 \pm 1.4$ & $55.3 \pm 5.6$ & - \\
\hline $\mathrm{Cd}$ & $<0.10$ & $3.75 \pm 0.01$ & - \\
\hline $\mathrm{Co}$ & $0.60 \pm 0.02$ & $3.71 \pm 0.02$ & - \\
\hline $\mathrm{Cr}$ & $17.2 \pm 0.5$ & $43.5 \pm 5.3$ & - \\
\hline $\mathrm{Cu}$ & $20.3 \pm 0.6$ & $79.2 \pm 0.2$ & $0.033 \pm 0.003$ \\
\hline $\mathrm{Fe}$ & $423 \pm 17$ & $579 \pm 9$ & $0.27 \pm 0.03$ \\
\hline $\mathrm{Ga}$ & - & - & $<0.01$ \\
\hline $\mathrm{Li}$ & $<0.1$ & $<0.1$ & - \\
\hline $\mathrm{Mg}$ & $5.17 \pm 0.15$ & $11.5 \pm 1.6$ & $<0.01$ \\
\hline $\mathrm{Mn}$ & $196 \pm 5$ & $228 \pm 7$ & $<0.01$ \\
\hline Mo & $<3,0$ & $9.74 \mathrm{~g} \cdot \mathrm{g}^{-1}$ & - \\
\hline $\mathrm{Ni}$ & $73.0 \pm 2.2$ & $75.8 \pm 1.4$ & $<0.01$ \\
\hline $\mathrm{Pb}$ & $<6.0$ & $<6,0$ & - \\
\hline $\mathrm{S}$ & - & - & $0.031 \pm 0.002$ \\
\hline $\mathrm{Si}$ & $36.4 \pm 1.9$ & $500 \pm 10$ & $0.20 \pm 0.07$ \\
\hline $\mathrm{Sn}$ & $11.1 \pm 2.5$ & $216 \pm 18$ & - \\
\hline $\mathrm{Ti}$ & - & - & $<0.01$ \\
\hline $\mathrm{U}$ & Balance & Balance & - \\
\hline $\mathrm{V}$ & $0.80 \pm 0.21$ & $10.1 \pm 0.2$ & - \\
\hline $\mathrm{Zn}$ & $1.64 \pm 0.28$ & $<1.0$ & $<0.01$ \\
\hline
\end{tabular}

by metallographic preparation of interfaces for contact with the aluminum in the diffusion couples. The tablets were polished by diamond paste of $3 \mu \mathrm{m}$.

The sets containing the tablets were welded. Each set was then heated at $540{ }^{\circ} \mathrm{C}$ during 15 minutes before being hot rolled, then hot rolled by a single pass of $38 \%$ reduction. The final thickness of the plate was $7.35 \pm 0.01 \mathrm{~mm}$. The samples were identified and cut by guillotine. X-ray images were taken to guide the pairs positioning. The hot rolling fabrication had no material losses. The SEM in Figure 4a shows how uniform was formed the interdiffusion line. The heat treatment of diffusion couples was made in a resistance furnace with no atmosphere conditioning. These treatments are listed in Table 2. The cooling was made in room conditions.

The microstructure of the samples was observed and analyzed with optical microscopy (OM) and scanning electron microscopy (SEM JXA system Jedle 6400) with (EDS). The XRD was made by Rigato Multiflex diffractometer $(\mathrm{CuK} \alpha 1.54056 \AA)$. The raw materials were chemically characterized by infrared techniques, ICP-OES, $\mathrm{X}$-ray fluorescence spectrometry and gravimetry.

\section{Results and Discussion}

The chemical analyses of the uranium and the aluminum alloy AA1050 brought many constituents to the system of interdiffusion analysis. Silicon impurity is the major concern since the literature cogitates of its hindrance for interdiffusion between $\mathrm{Al}$ and U-Mo pairs. Microstructures of U-10Mo alloy prior to heat treatment are shown in Figure 1a, b. In these micrographs, there are punctual regions of a second phase. By SEM/EDS, these regions displayed high content of $U$ and absence of Mo. These regions are probably associated with oxides of uranium as observed in XRD shown in Figure 2.

The major material phase is $\gamma$-phase (U, Mo) (light area). This phase, as seen in Figure 1, by means of SEM, revealed a dendrite formation caused by the peritectic solidification of $\gamma$-phase. The difference in composition of (U, Mo), estimated qualitatively by EDS, was around 1 at\% U. After homogenization of U-10Mo sample by means of heat treatment at $1000{ }^{\circ} \mathrm{C}$ during 72 hours, no greater structural changes were observed by XRD. The main result was to get slightly better definition in U-10Mo peaks after heat treatment. As shown in Figure 2, the XDR diffraction pattern revealed only the presence of metastable $\gamma$-phase with minor presence of uranium oxides.

Seong et al. ${ }^{15}$ suggested, by means of neutron diffraction, that the formed phase in $\mathrm{U}-10 \mathrm{Mo}$ is $\mathrm{U}_{2} \mathrm{Mo}$ with structural

Table 2. Sample heat treatments to simulate IL formation.

\begin{tabular}{ccc}
\hline Samples Id & Time (minutes) & Temperature $\left({ }^{\circ} \mathbf{C}\right)$ \\
\hline PL (1A) & 4800 & 550 \\
PL (1B) & 2400 & 550 \\
PL (2A) & 300 & 550 \\
PL (2B) & 2400 & 150 \\
PL (3) & 15 & 540 \\
\hline
\end{tabular}


characteristics of the space group P-4m2 (115 tetragonal: $\mathrm{a}=\mathrm{b}=4.8305 \AA, \mathrm{c}=3.418 \AA$ ). According to a more updated article, Sinha et al. ${ }^{16}$ proposed that the major structure might be analyzed as a bcc-structure ( $\mathrm{Im}-3 \mathrm{~m})$ of uranium receiving

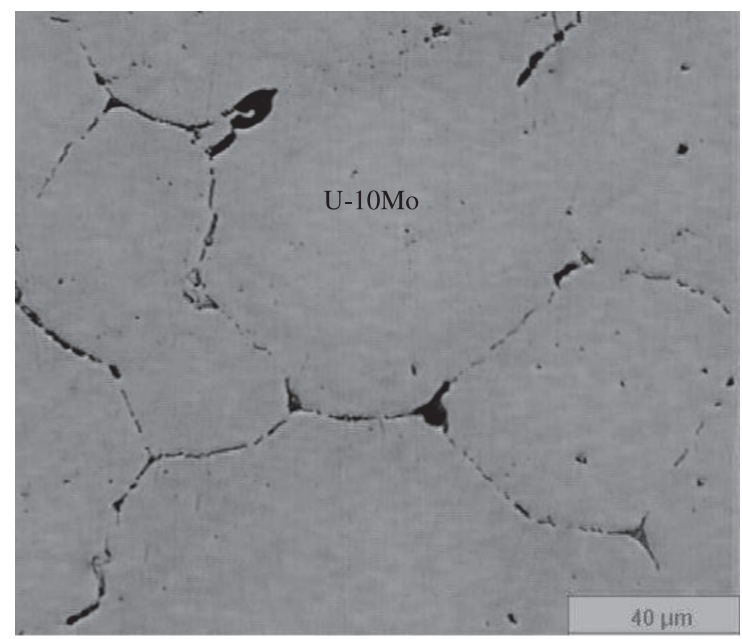

(a)

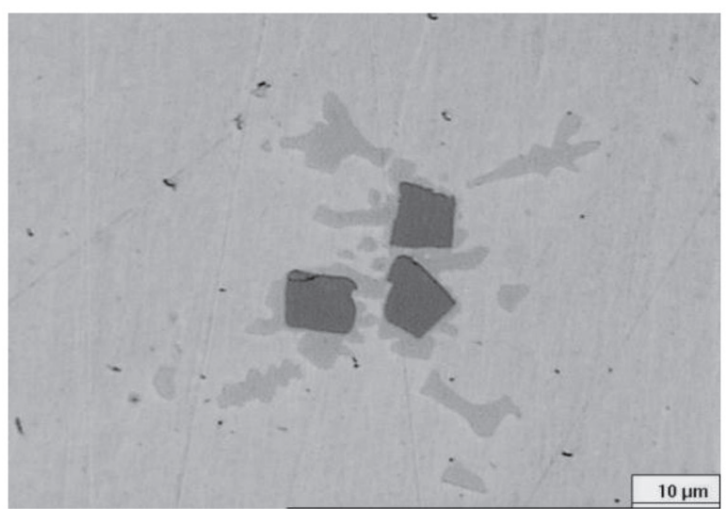

(b)

Figure 1. SEM Microscopy of (a) U-10Mo as cast (b) Region with second phase evidence.

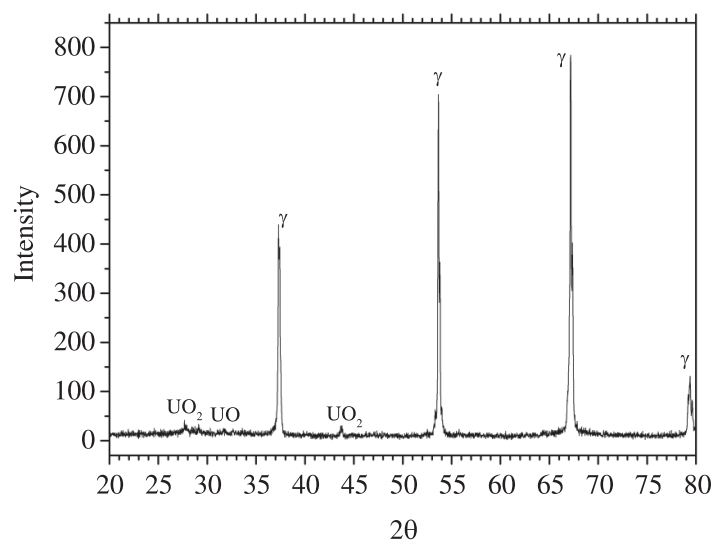

Figure 2. X-ray diffraction pattern showing U-10Mo treated at $1000{ }^{\circ} \mathrm{C}$ during 72 hours. substitutional Mo atoms in $\gamma$-uranium. In this work, it was found the same pattern as proposed by Sinha, as shown in diffractogram of Figure 2.

The analysis of heat treated samples allowed preliminary evaluation of the interdiffusion of $\mathrm{Al}$ in the area of U-10Mo alloy. The resulting structure revealed a layer of chemical interaction between the constituents AA1050 and $\gamma(\mathrm{U}, \mathrm{Mo})$.

The heating time to reach rolling temperature of the samples showed to be very important. Heating during 15 minutes at $540{ }^{\circ} \mathrm{C}$ was sufficient to promote a rapid evolution in aluminum diffusion inside U-10Mo, as shown in Figure 3a. Within this short soaking time, it was sufficient to allow aluminum diffusion towards the alloy. It reached a fixed amount of $\sim 8$ at $\% \mathrm{Al}$ in more than $170 \mu \mathrm{m}$ inside $\mathrm{U}-10 \mathrm{Mo}$ region. It suggested that $\mathrm{Al}$ reaches the maximum solid solubility around this level in U-10Mo. No corroboration to this fact was found in known literature for the alloy studied in this work. By EDS analysis, it was detected that no saturation of $\mathrm{Al}$ happened during this small soaking time at $550{ }^{\circ} \mathrm{C}$. Nevertheless, the interdiffusion phenomena allowed reaching 2 at $\% \mathrm{Al}$ at sample center $(\sim 1000 \mu \mathrm{m}$ from interface) within 15 minutes of heating at $550{ }^{\circ} \mathrm{C}$. From technological point of view, this heat treatment time simulated the heating for the hot rolling first pass of a MTR fuel plate, which would allow Al-diffusion occurring towards U-10Mo, before any neutron irradiation would promote this interdiffusion.

The heating treatments $\left(150{ }^{\circ} \mathrm{C}\right.$ and $\left.550{ }^{\circ} \mathrm{C}\right)$ at higher time $(5,40$ and 80 hours) in this study did not reproduced expected continuous raise of $\mathrm{Al}$ contents beyond 8 at\% $\mathrm{Al}$, as it would be forecast considering the majority of other interaction layer studies ${ }^{4,9}$. With longer periods of soaking, it was observed that the level of aluminum did not surpass the level of 8 at $\%$ in the material bulk.

After 80 hours of soaking, the interdiffusion sample at $550{ }^{\circ} \mathrm{C}$, as could be seen in Figure 4, showed a very thin region $(\sim 1 \mu \mathrm{m})$, where $\mathrm{Al}$ reached an amount of 11 at $\% \mathrm{Al}$ in average by means of qualitative EDS measurements. This amount is not far beyond the 8 at $\% \mathrm{Al}$ and should be considered insecure from experimental basis, since the

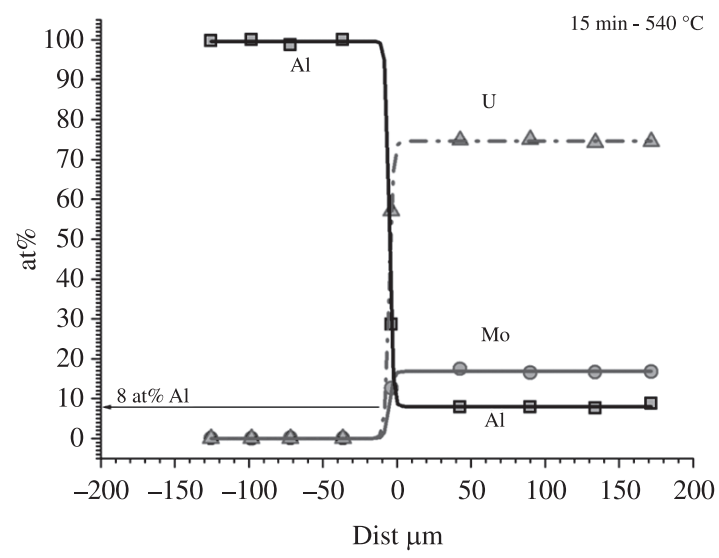

Figure 3. EDS curves at U-10Mo/AA1050 interface showing the interdiffusion curves after 15 minutes soaking of at $540{ }^{\circ} \mathrm{C}$. 


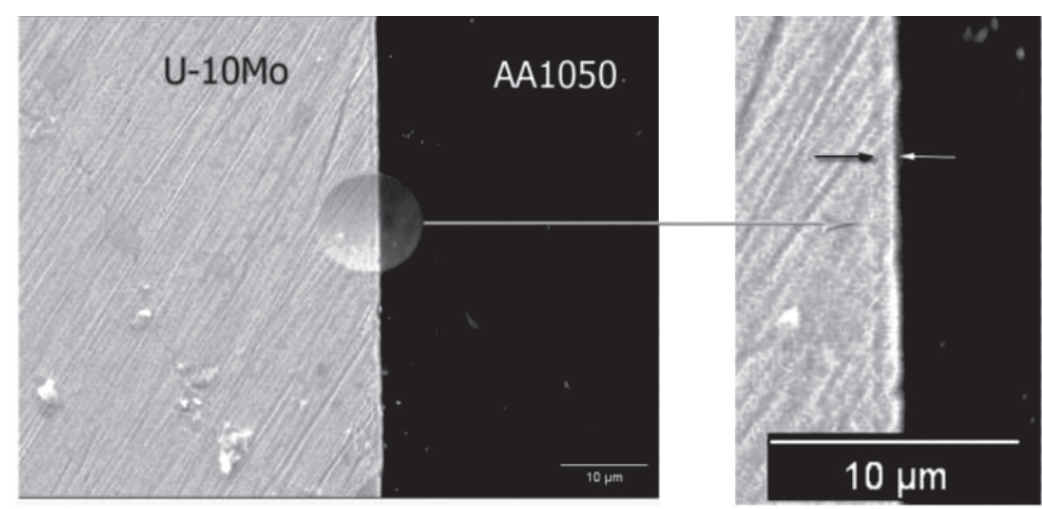

(a)

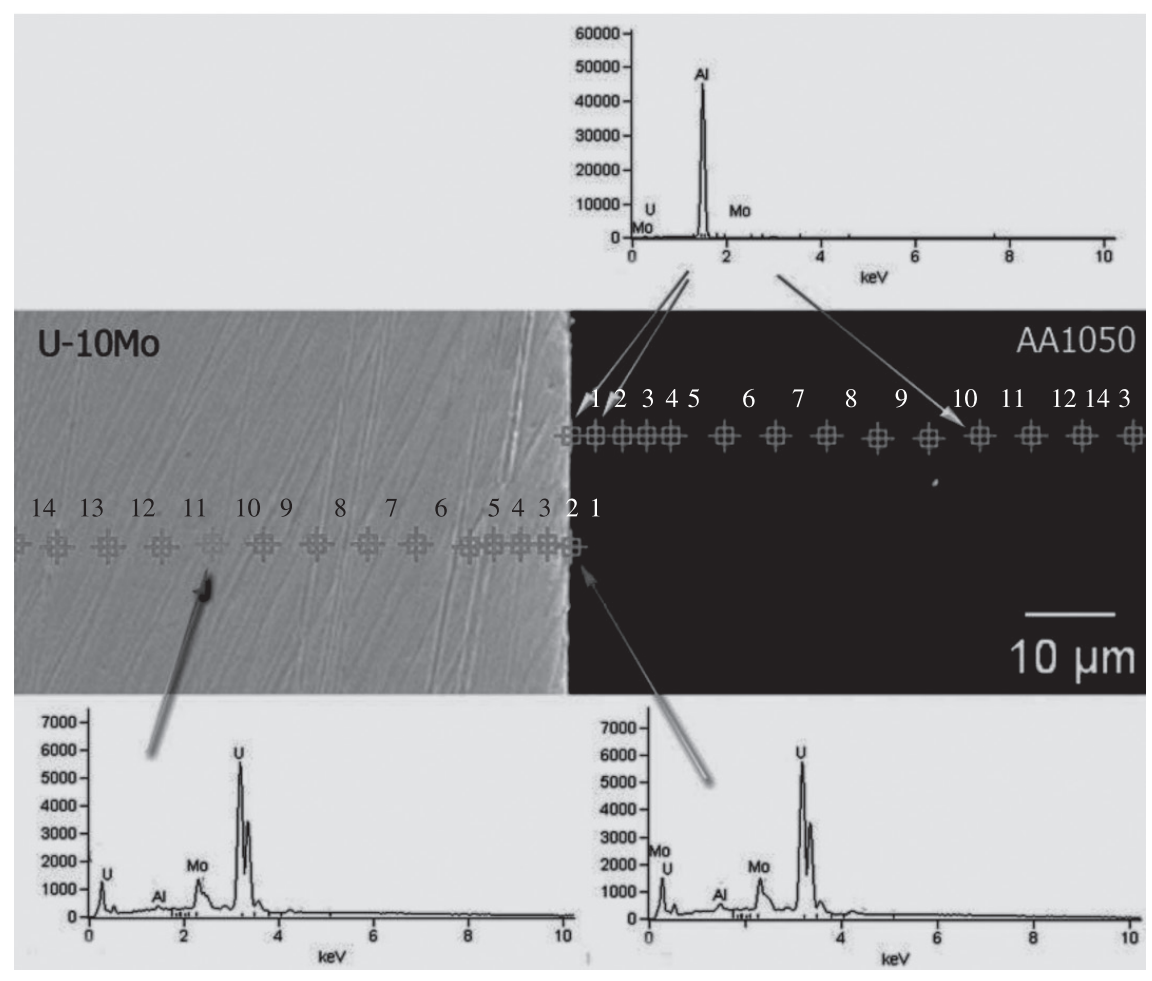

(b)

Figure 4. Interdiffusion pair U-10Mo/AA1050 after heat treatment of 80 hours at $550{ }^{\circ} \mathrm{C}$. (a) General view and magnification at right side showing the interaction layer; (b) EDS analisys of the same sample.

evaluations of EDS analysis is very close to the interface of aluminum interface. Comparing this data with $\mathrm{Ryu}^{9}$, it is possible to say that the present study results did not show an intense Al-interdiffusion inside U-10Mo, as expected. Relevant information was obtained by EDS line-scanning, since it was perceived a silicon interdiffusion towards the $\mathrm{U}-10 \mathrm{Mo}$ very near the interface, as shown in Figure 5. This could be an explanation for the interference of another element participating in alloying process. The results of Mirandou et al. ${ }^{12}$ in relation to silicon influence in formation of interaction layer U-10Mo/AA6061 is relevant and in the present work may be indicative of blockage cause.

As an argument to the present experimental results, the results led to think that an interdiffusion barrier was formed by residual elements co-diffusion with aluminum. As a consequence, this barrier promoted lesser interdiffusion phenomena between U-10Mo and alloy AA1050. Silicon co-diffusion with $\mathrm{Al}$, along the interdiffusion line, is thought to be an important indication for this interdiffusion blockage, as shown in Figure 5. 


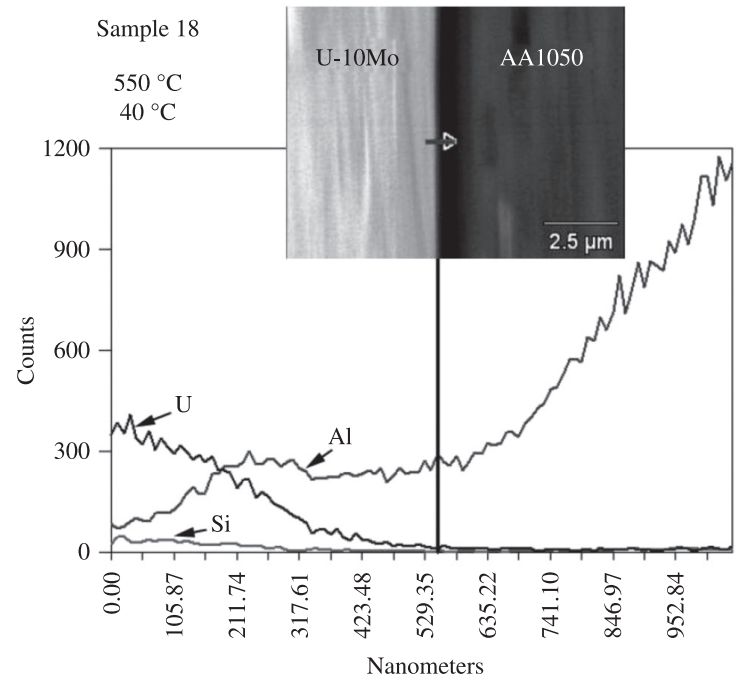

Figure 5. EDS curves at U-10Mo/AA1050 interface showing the evidence of Si-diffusion towards U-Mo area after 40 hours at $550{ }^{\circ} \mathrm{C}$.

\section{Conclusions}

As U-Mo alloys are very reactive with $\mathrm{Al}$, interdiffusion reaction are normally expected to be formed in the interface $\mathrm{U}-\mathrm{Mo} / \mathrm{Al}$. In this work, experiments with interdiffusion couples of U-10Mo/AA1050 revealed that interaction layer was very poorly formed.

During sample heat treatment with 15 minutes at $540{ }^{\circ} \mathrm{C}$, there was a rapid Al-diffusion inside U-10Mo structure, sufficient to reach steadily 8 at\% Al until $170 \mu \mathrm{m}$ from interdiffusion interface. Experimental evidences indicated that this might be a limit level for the considered experimental pair U-10Mo/AA1050. This experimentation showed, along the interdiffusion line, that a very thin interaction layer was formed by residual elements co-diffusion with Al, which highly prevented aluminum interdiffusion towards U-10Mo bulk. Silicon, which is residually present in AA1050, is supposed to have promoted this blockage.

\section{References}

1. Hofman GL. A short note on high density dispersion fuel. Argonne National Laboratory; 1996. http://dx.doi. org $/ 10.2172 / 373920$

2. Hofman GL and Meyer MK. Design of high density gammaphase uranium alloys for LEU dispersion fuel applications. In: Proceedings of the 1998 International Reduced Enrichment for Test Reactor Conference; 1998; Sao Paulo. Sao Paulo: RERTR; 1998

3. Hofman GL, Meyer MK, Snelgrove JL, Dietz ML, Strain $\mathrm{RV}$ and Kim K-H. Initial assessment of radiation behavior of very-high-density LEU fuels. In: Proceedings of the 1999 International Meeting RERTR; 1999; Budapest. Budapest: RERTR; 1999.

4. Hofman GL, Snelgrove JL, Hayes SL and Meyer MK. Progress in development of low enriched U-Mo dispersion fuels. In: Transactions of the Internacional Meeting on Research Reactor Fuel Manegement; 2002; Ghent. Ghent; 2002.

5. Durand JP, Lavastre Y and Grasse M. Report ANL/TD/TM99-06. RERTR, ANL; 1999.

6. Saliba-Silva AM, Durazzo M, Urano de Carvalho EF and Riella HG. Fabrication of $\mathrm{U}_{3} \mathrm{Si}_{2}$ powder for fuels used in IEA-R1 nuclear research reactor. Materials Science Forum. 2008; 591-593:194-199. http://dx.doi.org/10.4028/www. scientific.net/MSF.591-593.194

7. Saliba-Silva AM, Urano de Carvalho EF, Riella HG and Durazzo M. Research Reactor Fuel Fabrication to Produce Radioisotopes. In: Singh N, editor. Radioisotopes - Applications in Physical Sciences. InTech; 2011.

8. Mazaudier F, Proye C and Hodaj F. Further insight into mechanisms of solid-state interactions in $\mathrm{UMo} / \mathrm{Al}$ system. Journal of Nuclear Materials. 2008; 377(3):476-485. http:// dx.doi.org/10.1016/j.jnucmat.2008.04.016

9. Ryu HJ, Kim YS and Hofman GL. Characterization of the interaction products in U-Mo/Al dispersion fuel from in-pile and out-pile tests. In: Proceedings of the 2006 International Reduced Enrichment for Research and Test Reactors Meeting; 2006; Cape Town. Cape Town: RERTR; 2006.

10. Palancher H, Martin P, Nassif V, Tucoulou R, Proux O, Hazemannet J-L et al. Evidence for the presence of U-Mo-Al ternary compounds in the $\mathrm{U}-\mathrm{Mo} / \mathrm{Al}$ interaction layer grown by thermal annealing: a coupled micro X-ray diffraction and micro X-ray absorption spectroscopy study. Journal of Applied Crystallography. 2007; 40(6):1064-1075. http://dx.doi. org/10.1107/S0021889807040010

11. Mirandou M, Aricó S, Rosenbusch M, Ortiz M, Balart S and Gribaudo L. Characterization of the interaction layer grown by interdiffusion between U-7wt\% Mo and Al A356 alloy at 550 and $340{ }^{\circ}$ C. Journal of Nuclear Materials. 2009; 384(3):268-273. http://dx.doi.org/10.1016/j.jnucmat.2008.11.035

12. Mirandou MI, Aricó SF, Balart SN and Gribaudo LM. Characterization of the interaction layer in diffusion couples U-7 wt.\% Mo/Al 6061 alloy at $550{ }^{\circ} \mathrm{C}$ and $340{ }^{\circ} \mathrm{C}$. Effect of the $\gamma \mathrm{U}(\mathrm{Mo})$ cellular decomposition. Materials Characterization. 2009; 60(8):888-893. http://dx.doi. org/10.1016/j.matchar.2009.02.010

13. Saliba-Silva AM, Martins IC, Oliveira ET, Pereira JV and Durazzo M. Estudos térmicos e físicos para viabilizar a redução metalotérmica de urânio metálico a partir de UF4. Revista Brasileira de Pesquisa e Desenvolvimento. 2006; 8:85-90.

14. Saliba-Silva AM, Souza JAB, Frajndlich EUC, Perrotta, JA and Durazzo M. First Results of $\mathrm{U}_{3} \mathrm{Si}_{2}$ Production and its Relevance in the Power Scaleup of IPEN Research Reactor IEA-R1m. In: Proceedings of the 1997 International Reduced Enrichment for Research and Test Reactors Meeting; 1997; Jackson Hole. Jackson Hole: RERTR; 1997.

15. Seong B-S, Leea C-H, Leea J-S, Shima H-S, Leea J-H, Kim $\mathrm{KH}$ et al. Neutron diffraction study of $\mathrm{U} \pm 10 \mathrm{wt} \%$ Mo alloy. Journal of Nuclear Materials. 2000; 277(2-3):274-279. http:// dx.doi.org/10.1016/S0022-3115(99)00198-1

16. Sinha VP, Hegde PV, Prasad GJ, Dey GK and Kamath HS. Phase transformation of metastable cubic $\gamma$-phase in U-Mo alloys. Journal of Alloys and Compounds. 2010, 506(1):253-262. http://dx.doi.org/10.1016/j.jallcom.2010.06.187 